\title{
An interdisciplinary scenario analysis to assess the water availability and water consumption in the Upper Ouémé catchment in Benin
}

\author{
S. Giertz ${ }^{1}$, B. Diekkrüger ${ }^{1}$, A. Jaeger ${ }^{1}$, and M. Schopp ${ }^{2}$ \\ ${ }^{1}$ Institute of Geography, University of Bonn, Germany \\ ${ }^{2}$ Institute for Agricultural Policy, Market Research and Economic Sociology, University of Bonn, Germany \\ Received: 23 January 2006 - Revised: 22 May 2006 - Accepted: 3 July 2006 - Published: 26 September 2006
}

\begin{abstract}
This paper presents an interdisciplinary scenario analysis to assess the influence of global and regional change on future water availability and water consumption in the Upper Ouémé catchment in central Benin. For the region three development scenarios were evolved. These scenarios are combined with climate change scenarios based on the IPCC (Intergovernmental Panel on Climate Change). In the modelling approach the quantification of the land use/land cover change is performed by the cellular automata model CLUE$\mathrm{S}$. The future climate scenarios are computed with the regional climate model REMO driven by the global ECHAM model. Using this data different land use and climate change scenarios can be calculated with the conceptual hydrological model UHP-HRU to assess the effects of global changes on the future water availability in Benin.

To analyse the future water availability also the water consumption has to be taken into account. Due to high population growth an increase in water need in the future is expected for the region. To calculate the future household water consumption data from a regional survey and demographic projections are used. Development of the water need for animal husbandry is also considered.

The first test run of the modelling approach was performed for the development scenario 'business as usual' combined with the IPCC scenario B2 for the year 2025. This test demonstrates the applicability of the approach for an interdisciplinary scenario analysis. A continuous run from 20002025 will be simulated for different scenarios as soon as the input data concerning land use/land cover and climate are available.
\end{abstract}

Correspondence to: S. Giertz

(sgiertz@uni-bonn.de)

\section{Introduction}

The shortage of fresh water resources is a severe problem in many regions of the world. This problem will aggravate in future. Already in 2025 about four billion people - the half of the world population - will live in countries with high water stress (Cosgrove and Rijsberman, 2000). The reason for that is not only the high population growth, but also the effects of global environmental changes on the water cycle. Global change is a complex phenomenon including not only climate and land use change but also socio-economic changes. Therefore an interdisciplinary approach is necessary to assess the regional impacts of global change on the future development of the environment and the resources of a region. In the course of the global change discussion many investigations which analyse the impacts of these changes on future water resources were carried out. The WAVES-program for instance investigated the effects of global change in the semiarid environment of northeast Brazil (Gaiser et al., 2003) in an interdisciplinary approach. Other investigations were carried out by Mimikou et al. (2000), Lahmer et al. (2001), Legesse et al. (2003), Ojo et al. (2003), but they often include only climate or land use change. Often hydrological models are used in these investigations to assess the impact on the water resources, but the combination of different models (hydrologic, climatic, demographic models and land use and cover change (LUCC) models) as performed in this study is rather seldom.

The presented study is integrated in the GLOWA-program, which was launched in 2000 by the German Federal Ministry of Education and Research. This program aims to analyse the impact of global change on the water cycle in catchments in different climatic zones. The IMPETUS-project, which is part of the GLOWA-programm, focuses on two catchments in West Africa: the wadi Drâa in Morocco and the river Ouémé in Benin (Speth et al., 2002, 2005). The aim of this study is to develop and to describe the methods used for an

Published by Copernicus GmbH on behalf of the European Geosciences Union. 


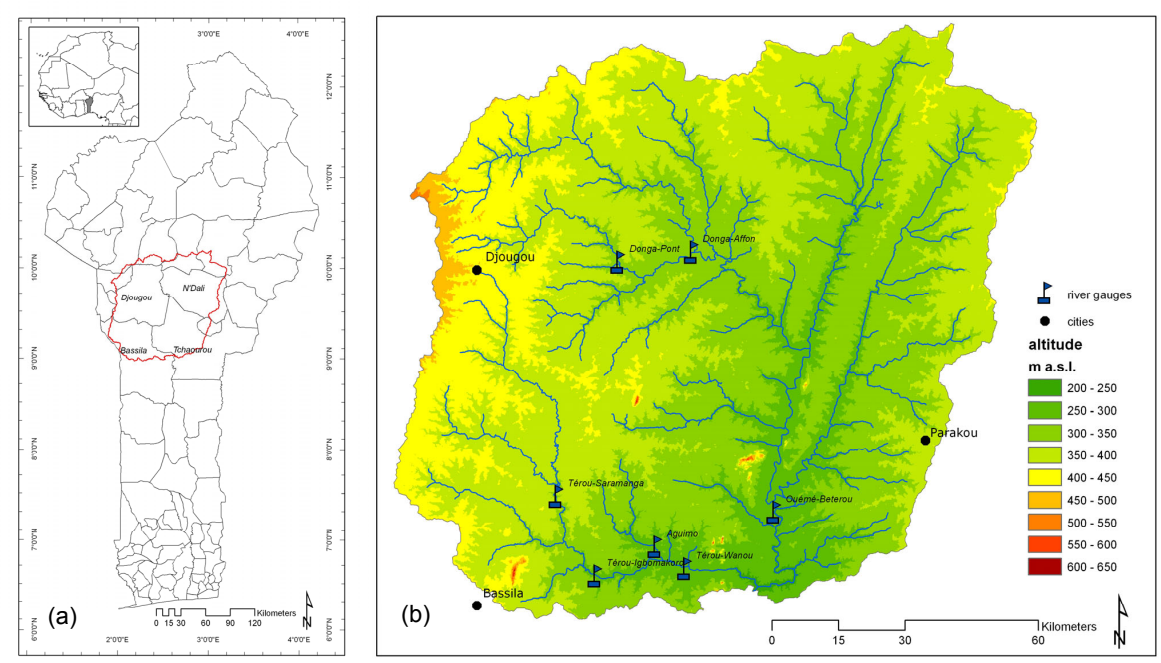

Fig. 1. (a) Benin with communal borders and Upper Ouémé catchment. (b) Upper Ouémé catchment with river gauges of CATCH-project and Direction Général de l'Hydraulique used for model validation.

interdisciplinary assessment of future water availability and water consumption in the Ouémé catchment in Benin.

\section{The Upper Ouémé catchment in view of global change}

In Benin the IMPETUS-project focuses on the Upper Ouémé catchment, which has a size of $14300 \mathrm{~km}^{2}$ (Fig. 1). It is located in the sub-humid Sudan-Guinea-Zone in central Benin. This region is characterized by a unimodal rainy season from May to October with a mean annual precipitation of $1100 \mathrm{~mm}$ per year. The mean temperature is $26.4^{\circ} \mathrm{C}$. Due to the lack of rainfall during the dry season the river discharge occurs only periodically from June to December.

The geomorphology of the catchment is characterized by a flat, undulating pediplain relief with altitudes from 227 to $616 \mathrm{~m}$ above sea level (Fig. 1). The region belongs to the precambrian basement complex which is mainly composed of migmatite. The main soil types of the catchment are Lixisols and Acrisols according to the World Reference Base classification (ISSS Working Group RB, 1998). Near the rivers also hydromorphic soils occur. The vegetation is mainly composed of moist savannah. 14\% of the catchment is actually used as field.

During the last decades global and regional change effects were observed in the region. As a result of climate change precipitation decreases and the rainy season shortens, which causes a reduction of river flow in the region, e.g. at the Ouémé-Béterou river gauge (Speth et al., 2002). The land use/land cover change in the Upper Ouémé catchment was investigated by Judex (2003) comparing a land use/land cover classification from 1991 and 2000, derived from LANDSAT ETM+ data. According to this investigation the land cover change is particularly high in the south- ern part of the Upper Ouémé catchment. As an example, in the commune Tchaourou an increase of cultivated area of $261 \%$ was determined, while in the commune of Bassila an increase of $127 \%$ was detected. In the northern part of the catchment (commune Djougou and N'dali) the ratio of agricultural area is already high, therefore the increase was only $50 \%$. The reason for this extreme increase of agricultural area in the southern part of the Upper Ouémé catchment is the immigration of over 10000 people within the last 5 years in this sparsely populated region with less than 10 inhabitants per $\mathrm{km}^{2}$. This has caused a high population growth of $4.86 \%$ per year from 1992 to 2002 compared to the mean national growth of about 2.9\% per year (Doevenspeck, 2005). As land availability is high in the southern part of the catchment, people migrate from other regions in Benin (mainly northwest of Benin and the bordering regions to Togo) because of land scarcity and decreasing soil fertility. In contrast to these regions the land availability in the southern part of the Upper Ouémé catchment is relatively high. Due to a low productivity of the subsistence agriculture and the absence of resource management institutions deforestation and the increase of agricultural area is a very rapid process in the target region. Settlers in the southern part of the Upper Ouémé catchement clear about 1500 hectares of savannah and woodland per year in order to cultivate mainly yam (Doevenspeck, 2005), which is the most important food crop in the region. The conversion from savannah or woodland to fields is performed by slash-and-burn techniques. 


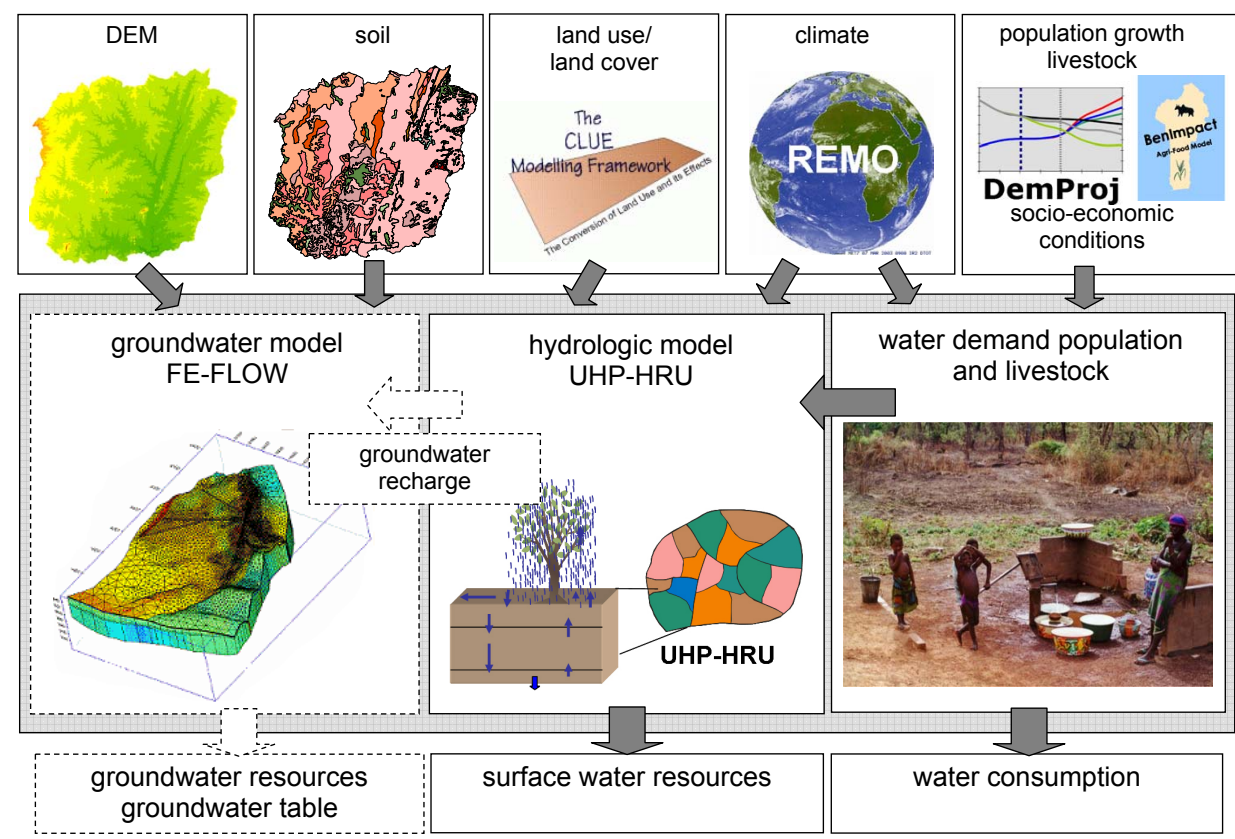

Fig. 2. Interdisciplinary modelling approach to assess future water availability. Dashed lines: planned components.

\section{Scenarios of regional development and climate change scenarios}

In order to investigate the effects of global and regional change on the water resources scenarios of the regional development were evolved for Benin. Scenarios are consistent and plausible images of alternative futures that are rich enough to support the decision making process. A meaningful scenario shows different societal, ecological and technological aspects of the system under investigation. Scenarios are not predictions and should not be qualified by a probability. Instead, they allow for the analysis and assessment of alternative development paths of complex systems. The basic characteristics and the main driving forces, as well as their interactions are usually described in so-called narrative "storylines" (Speth et al., 2005).

The scenario building approach comprises seven steps starting with a problem analysis and the definition of the basic scenarios and their main characteristics and scales (Speth et al., 2005).

To characterize the scenarios indicators and driving forces were determined and qualitatively described. For Benin three base scenarios were developed for the time period of 20002025:

Scenario B1 "Economic growth and consolidation of decentralization" describes a scenario of political stability and economic growth. Living conditions of the population improve and the overall pressure of resource depletion decreases due to technical innovations.

Scenario B2 "Economic stagnation and institutional insecurity" sketches a development path of a continuing and mu- tually influencing spiral of political destabilisation and economic depression. Declining world market prices for the main export products, decreasing grants of donor assistance and declining rates of regional and local economic cooperation lead to a negative overall economic development which undermines also the political stability of the country. Living conditions worsen or stagnate on a low level. Resource depletion and resulting conflicts increase.

Scenario B3 "Business as usual" extrapolates the current trends. Against this background there is no general increase of economic development and social welfare. The country is successful in maintaining its political stability but fails in improving its position on the world markets and its overall competitiveness. Population growth continues to decline and the traditional power structures on the local level remain rather unchanged.

The scenarios are specified for each scenario region: the Upper, Middle and Lower Ouémé (Speth et al., 2005).

To simulate scenarios of future water availability the described development scenarios are combined with different IPCC climate change scenarios (IPCC, 2001) which are calculated by a chain of climate models (see Sect. 4.3). For the first scenario calculation of this study the IPCC scenario B2 was used. The B2 storyline and scenario family describe a world in which the emphasis is on local solutions to economic, social, and environmental sustainability. It is a world with continuously increasing global population, intermediate levels of economic development. While the scenario is also oriented towards environmental protection and social equity, it focuses on local and regional levels. 


\section{Modelling concept}

To assess the effects of global change on the water resources an interdisciplinary modelling approach is applied. An overview of the modelling approach is given in Fig. 2. As shown in the figure the model UHP-HRU is used to calculate the hydrological processes. For a better representation of the groundwater flow it is planned to integrate the FEFLOWmodel (WASY, 2004) in the approach. As the calibration of the model is not finished yet, the integration of the model is not yet realized.

In the scenario modelling process the time variant input parameters are calculated by other models, as shown in Fig. 2. The LUCC (Land use and cover change) modelling is performed with the model CLUE-S (Verburg et al., 2002) by the remote sensing research group of the IMPETUS project. The climate scenarios are calculated with the REMO model, which is nested in the General Circulation Model (GCM) ECHAM (see Sect. 4.3). To assess the future water consumption data of domestic water use of Hadjer et al. (2005) and Schopp (2004) are used in combination with demographic projections of Heldmann (2006) and INSAE (2004). The animal water need is calculated by Gruber and Kuhn (2006) based on agro-statistical data.

\subsection{The hydrological model UHP-HRU}

\subsubsection{Model concept and parameterization}

The lumped model UHP (Bormann and Diekkrüger, 2004), which was successfully tested for several sub-catchments of the Ouémé river, was modified to the spatial distributed model UHP-HRU. It is a conceptual model, which takes into account all relevant hydrological processes like evapotranspiration, surface runoff, interflow, percolation, groundwater recharge etc. The model is composed of three linear storages: the root zone storage, unsaturated zone storage and saturated zone storage. They are linked via percolation and capillary rise. The potential evapotranspiration is optionally calculated with Penman (1956), Turc (1963) or Priestley and Taylor (1972). For the computation of the surface runoff the SCS curve number approach is used (SCS, 1972).

The spatial discretization is carried out according to the hydrologic response units (HRUs) concept. To define these HRUs the catchment is subdivided into small sub-catchments with ArcHydroTools using a digital elevation model (DEM). A further subdivision in HRUs is performed by a superposition with a soil and a land use map. According to this procedure the Upper Ouémé catchment was subdivided in 526 sub-catchments and 3517 HRUs.

For the discretization of the Upper Ouémé catchment the DEM from the SRTM mission from the USGS (http://srtm. usgs.gov/) was used. The existing soil map for Benin (scale 1:200 000, Faure, 1977) contains no information about soil physical properties. In order to get the required soil data for model parameterization analyses of soil physical properties for representative soil profile for each soil type were carried out in the Upper Ouémé catchment during the first and second phase of the IMPETUS-project (Junge, 2004; Giertz, 2004; Sintonjji, 2005). The vegetation parameters were taken from investigations in the Upper Ouémé catchment from Orthmann (2005) and Mulindabigwi (2005). Missing data were taken from Scourlock et al. (2001). These parameters were considered as constant for the scenario calculation.

\subsubsection{Model validation}

The model was tested in different sub-catchments of the Ouémé river for available discharge data of the period 19932003. The lumped version of the UHP model was calibrated and validated using data from the Térou-Wanou catchment (3133 km²; Bormann and Diekkrüger, 2004). A further calibration of the distributed model was not required. As the model contains no routing routine the model validation of the distributed model was carried out in a weekly time step. As shown in Table 1 the model results are good for all subcatchments. As the validation was performed in catchments with different land cover (Donga: high ratio of agricultural area, Térou: mainly savannah and woodland), the application of the model for land use change scenarios is feasible. Due to the high inter and intra-annual variability of the rainfall amount, the model has to deal with dry and wet conditions during the validation period. Therefore the model is also applicable for changing climate condition (e.g. reduction of rainfall).

\subsection{LUCC modelling}

The LUCC modelling is performed by Thamm et al. (2005) with the cellular automata model CLUE-S (Verburg et al., 2002). The spatially explicit model was successfully tested in different tropical environments (Verburg et al., 2004; Verburg et al., 2004a).

The setup of the CLUE-S model requires probability layers for each land-cover class, conversion information and future demand scenarios. Influences of different driving forces on land use and land cover were calculated with logistic regression in which the distance to roads, the distance to important settlements, the population density, the soil suitability for agriculture and the protected forest areas are used as independent variables (Thamm et al., 2005).

For the Upper Ouémé catchment the model was validated with land use/land cover classification of LANDSAT ETM+ scenes from 13.12.1991 and 26.10.2000 (Judex, 2003). The model output for the year 2000 was compared with the LANDSAT classification data. To assess the goodness of fit the ROC method (Pontius and Schneider, 2000) was used. This is an estimation similar to the $\mathrm{R}^{2}$ for ordinary linear regressions. For the simulated land cover change from 1991 to 2000 these values are between 0.69 and 0.99 for the different 
Table 1. Quality measures of UHP-HRU application in the Upper Ouémé catchment (validation period). Discharge data used for model validation provided by the CATCH-project and Direction Général de l'Hydraulique.

\begin{tabular}{lcccr}
\hline River, gauge & Catchment size $\left[\mathrm{km}^{2}\right]$ & Simulation period & Model efficiency & $\mathrm{r}^{2}$ \\
\hline Térou, Wanou & 3060 & $1993-2000$ & 0.79 & 0.80 \\
Térou, Saramanga & 1360 & $1998-2001$ & 0.81 & 0.77 \\
Térou, Igbomakoro & 2323 & $1998-2003$ & 0.84 & 0.81 \\
Aguimo & 396 & $1997-2003$ & 0.70 & 0.69 \\
Donga, Pont & 587 & $1998-2003$ & 0.73 & 0.72 \\
Donga, Affon & 1308 & $1998-2002$ & 0.81 & 0.80 \\
Ouémé, Bétérou & 10083 & $1997-2000$ & 0.82 & 0.75 \\
\hline
\end{tabular}

cover classes (Thamm et al., 2005). Consequently the model is able to explain the land cover change in the region with the chosen driving forces.

The first scenario calculation for the period 2000 to 2025 was performed for the 'business as usual' scenario in a yearly time step. The output data are yearly land cover maps with a resolution of $500 \times 500 \mathrm{~m}$. An amelioration of the resolution is in progress.

The generated land cover maps serve directly as input for the hydrological model.

\subsection{Climate modelling}

The climate modelling in the IMPETUS-project is performed on different spatial and time scales with a chain of climate models, which serves as dynamical downscaling approach. Each smaller-scale model is nested in the coarser resolved one, receiving the atmospheric forcing from the coarser resolved model (Paeth et al., 2005). The dynamic downscaling approach is used in IMPETUS because according to Paeth et al. (2005) the dynamic approach produces consistent data sets of all meteorological variables like rainfall, cloudiness, and humidity. On the global scale the GCM ECHAM is used. REMO is nested in the ECHAM-model and calculates the climatic processes on a spatial resolution of $0.5^{\circ} \times 0.5^{\circ}$. REMO is a hydrostatic regional climate model developed at the Max Planck Institute of Meteorology. Rainfall data are post-processed and adapted to measurements using model output statistics (Paeth et al., 2005; Paeth, 2006 ${ }^{1}$ ). A further downscaling is performed with the LM (Lokalmodell) of the German Weather Service and the FOOT3DK model, which can be used for regional and local investigations. As the scenario calculation with theses local models is not finished yet, the results of the REMO model were used to calculate the future scenario in this study (Speth et al., 2005).

Sensitivity studies with REMO (Paeth, 2004) have revealed that land degradation plays an important role in the

\footnotetext{
${ }^{1}$ Paeth, H.: Statistical postprocessing of simulated precipitation data for hydrological and climatological analyses in West Africa, Meteorol. Atmos. Phys., submitted, 2006.
}

atmospheric processes, especially in the Sahel and the Congo basin. Therefore, realistic climate predictions in Africa have to consider land degradation in addition to the greenhouse conditions. To calculate the scenarios with REMO the model was nested in the ECHAM 4 model with a quantification of greenhouse gases taken from IPCC scenarios. Additionally the large scale changes in land cover were implemented using FAO data. The comparison of simulated and measured rainfall amounts in Benin has shown that REMO is able to compute realistic precipitation amounts for the region (Paeth, 2004; Paeth et al., 2005; Paeth, 2006 ${ }^{1}$ ). Using this approach five time slices (2005, 2010, 2015, 2020 and 2025) were calculated for the IPCC scenario B2 with REMO. Actually consortial runs with REMO are performed for the period 2001 to 2050 using the new IPCC scenarios A1b and B1 with ECHAM5 forcing. These data will be used in future for the scenario analysis with the presented modelling approach.

The results of the REMO model are available in a $0.5^{\circ} \times 0.5^{\circ}$ grid. These data are directly used as input for the hydrological model.

\subsection{Water consumption}

As there is no industry in the Upper Ouémé catchment the water consumption is restricted to household and agricultural water use. The regional survey of Hadjer et al. (2006) revealed that nearly no irrigation is performed in the catchment. As the water use of crops is implied in the hydrologic model, only household and animal water consumption has to be taken into account.

To determine the household water consumption for the Upper Ouémé catchment data from the survey of Hadjer et al. (2005) and Schopp (2004) were used in combination with demographic data. Hadjer et al. (2005) and Schopp (2004) registered the water consumption of households in rural and urban areas of the Upper Ouémé catchment. The investigation was carried out for 6 month in 40 households and for one year in 16 households. They found out, that during the dry season less water is used (16.71/capita/day) than during the rainy season (20.91/capita/day), where more water is available. The study also revealed that the consumption of water 
Table 2. Climate modelling chain within the IMPETUS-project.

\begin{tabular}{llll}
\hline Model & Spatial & Temporal & Scope \\
\hline ECHAM & $300 \mathrm{~km}$ & 200 years & Global \\
REMO & $55 \mathrm{~km}$ & 30 years & Continental \\
LM & $7-28 \mathrm{~km}$ & 1 year & Regional \\
FOOT3DK & $1-9 \mathrm{~km}$ & 1 week & Local \\
\hline
\end{tabular}

depends particularly on access to water. Consequently the water consumption in the city is higher than in the village, where the water supply infrastructure is often very bad in central Benin.

The demographic data are obtainable from census data of INSAE (2003) for 1979, 1992 and 2002. For future scenarios the regionalized demographic projections from Heldmann (2006) based on national projections of INSAE (2004) were used. The projections were calculated from 2002 (last census) to 2025 for the three development scenarios with the model SPECTRUM DEM-Proj (http://www.policyproject. com). The model determined only small differences in the population number for the different scenarios.

In the presented modelling approach the model BenIMPACT of the Institute for Agricultural Policy, Market Research and Economic Sociology of the University of Bonn will calculate the water use of the livestock. As the development of the livestock module of BenIMPACT is not finished yet a calculation based on data of the agricultural statistic of Benin was used in combination with water consumption data (Gruber and Kuhn, 2006). For the scenario calculation the growth rate was taken from demographic projections.

\section{First scenario results}

A first test run of the modelling approach was performed for the Upper Ouémé catchment for the year 2025. In this first scenario analysis the development scenario B3 "business as usual" was combined with the IPCC climate scenario B2. As the calculation of the continuous climate scenarios and the development of all modelling tools are not finished yet, the following scenario results have to be considered as preliminary.

For the development scenario B3 the LUCC modelling shows an increase of agricultural area and a decrease of dense and sparse savannah from 2000 to 2025 (Table 3). The spatial distribution reveals that the expansion of agricultural area occurs mainly along roads and tracks, where the accessibility is easy.

Concerning the IPCC scenario B2 the REMO model shows an increase of temperature and a decrease of rainfall for the region. Compared with the mean precipitation from 1993-2003 the rainfall is $163 \mathrm{~mm}$ less in 2025 (Ta-
Table 3. Land cover in the Upper Ouémé catchment 2000 and 2025, scenario "business as usual" (Thamm et al., 2006).

\begin{tabular}{lcc}
\hline Land cover class [\%] & 2000 & 2025 \\
\hline Settlements & 0.3 & 0.4 \\
Agricultural area $>55 \%$ & 3.8 & 5.0 \\
Agricultural area $<55 \%$ & 32.2 & 55.5 \\
Forest & 0.6 & 0.6 \\
Dense savannah & 24.9 & 14.7 \\
Sparse savannah & 38.2 & 23.9 \\
\hline
\end{tabular}

ble 4). Due to a high interannual variability rainfall amounts of about $1000 \mathrm{~mm}$ occurred also during the last decades (e.g. 2001). Regarding all time slices the REMO simulation shows a trend of reduced rainfall in the future although for single years an increase compared to the long-term mean has been computed.

Figure 3 shows the comparison of the minimal, maximal and mean discharge at Ouémé-Beterou gauge from 19932003, the measured discharge for the year 2000 and the simulated discharge with UHP-HRU for the scenario 2025. Compared to the mean discharge from 1993-2003 and the discharge of the year 2000 the discharge period for 2025 is shorter. Striking is the reduction of discharge in the end of August, which does not occur in the period 1993-2003. This is caused by a strong reduction of precipitation in this period simulated by REMO. The comparison of measured and simulated rainfall for the period 1979-2003 revealed that the model tends to underestimate the rainfall in August (see Sect. 6, Fig. 7), which can also influence the scenario simulation.

According to the scenario simulation the renewable water resources are halved in 2025 compared to 1993-2003 for the region (Table 4). The reduction mainly results from the climate scenario input. The spatial distribution of the renewable water resources in 2000 and 2025 is shown in Fig. 4.

As only one time slice was calculated in this study no general conclusion concerning the further water availability can be drawn. Nevertheless, the results obtained here fit to other studies in that area. The study of Sintondji (2005) revealed that the general trend of decreasing discharge is also observable for the other time slices except for 2015. Sintondji computed discharge and erosion for a sub-catchment of the Ouémé river using the model SWAT in a much coarser resolution as considered here.

To assess the water consumption for 2025 the population growth and the increase of livestock have to be taken into account. According to the demographic projections of Heldmann (2006) the population in the Upper Ouémé catchment increases from about 329600 (census 2002) to 612500 inhabitants for the scenario B3. Based on these data the development of water consumption for each village considered 

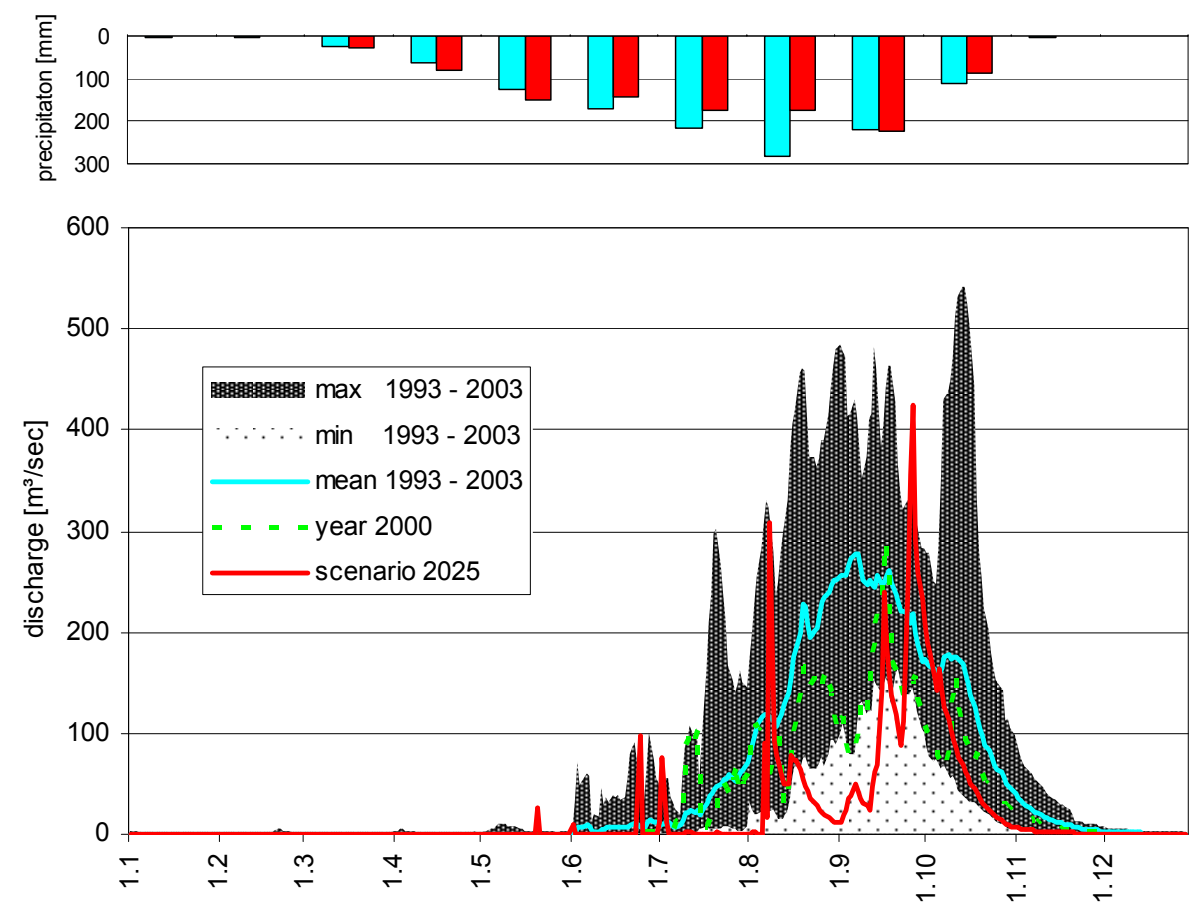

Fig. 3. Minimal, maximal and mean discharge at the Ouémé-Beterou gauge and mean precipitation of the period 1993-2003 compared with discharge and precipitation of 2025 for scenario B3 combined with IPCC B2. Additionally the discharge of the year 2000 is displayed for a better comparability of the annual discharge dynamics.

Table 4. Water balance of the period 1993-2003 and the scenario B3 year 2025 simulated with UHP-HRU.

\begin{tabular}{lll}
\hline & $1993-2003$ & 2025 \\
\hline Precipitation & $1229 \mathrm{~mm}$ & $1065 \mathrm{~mm}$ \\
Renewable water resources (groundwater recharge + discharge) & $265 \mathrm{~mm}$ & $120 \mathrm{~mm}$ \\
Storage in root zone, unsaturated zone and saturated zone & $83 \mathrm{~mm}$ & $59 \mathrm{~mm}$ \\
Evapotranspiration & $881 \mathrm{~mm}$ & $886 \mathrm{~mm}$ \\
Renewable water resources (groundwater recharge + surface water) & $3.8 \mathrm{~km}^{3}$ & $1.7 \mathrm{~km}^{3}$ \\
Water consumption in \% of the water resources & $2.8 \mathrm{Mio} \mathrm{m}^{3}$ & $6.6 \mathrm{Mio} \mathrm{m}^{3}$ \\
& $0.07 \%$ & $0.4 \%$ \\
\hline
\end{tabular}

in the census is calculated (Fig. 5). Calculations of Gruber and Kuhn (2006) revealed, that the water need for livestock is four times higher in 2025 compared with 2002, which is not only caused by an augmentation of the livestock number but also by an increase of water consumption by the animals, due to higher air temperatures. The development of water consumption from 1992 to 2025 is displayed in Fig. 6. Also the total water consumption increases strongly, it represents only $0.4 \%$ of the yearly water resources in the catchment (Table 4).

\section{Discussion of uncertainties within the modelling ap- proach}

The modelling process always implies uncertainties related to the model parameters and input data, the process description and the validation data. Bormann and Diekkrüger (2004) analysed the parameter uncertainty of the UHP model with the Latin Hypercube method. They showed that the uncertainty band is relatively narrow and the observed hydrograph (Térou catchment) lies within the uncertainty bands. The simulations of dry and wet years and the application of the model in catchments with different land use (see Sect. 4.1) have shown that the model is usable for scenario modelling in this region. 


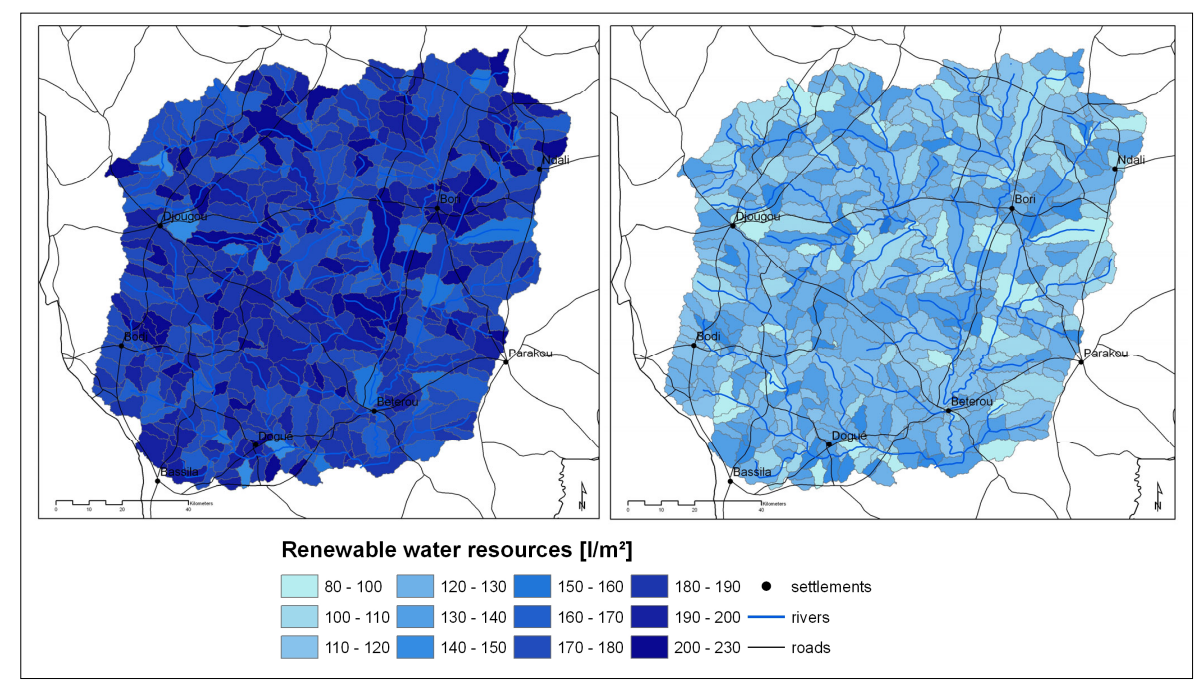

Fig. 4. Renewable water resources in the Upper Ouémé catchment 2000 and scenario 2025 (development scenario B3 in combination with IPCC scenario B2).

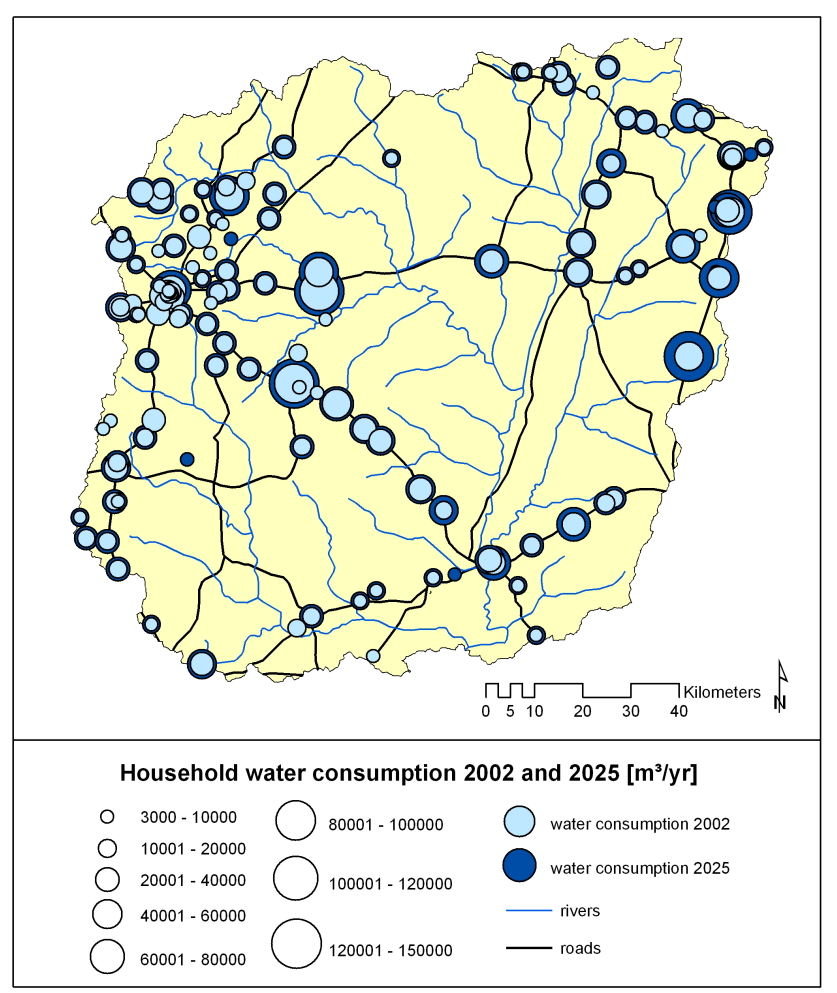

Fig. 5. Household water consumption in the Upper Ouémé catchment 2002 and scenario 2025.

As results from other models were used for the scenario calculation the uncertainty of these model results have to be taken into account in addition to the uncertainties of the hydrological modelling.

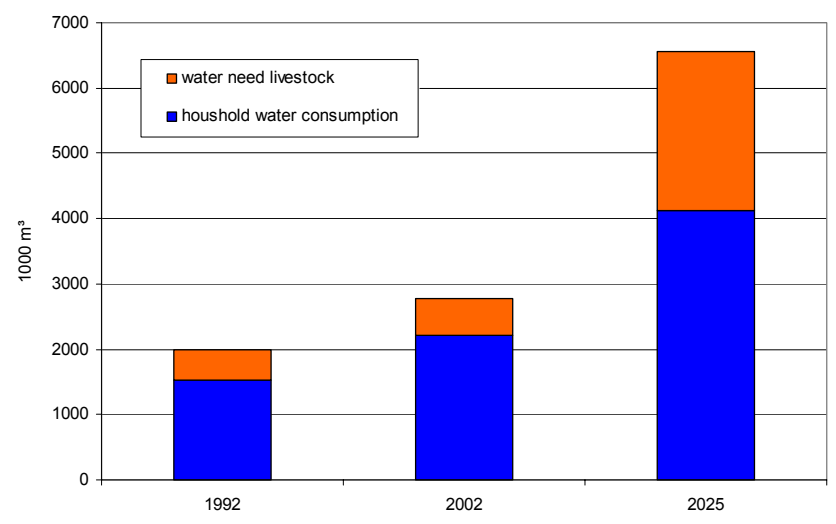

Fig. 6. Development of water consumption in the Upper Ouémé catchment.

The REMO model is a regional climate model with a grid size of $0.5^{\circ} \times 0.5^{\circ}$. The Upper Ouémé catchment is covered by only 10 pixels. An implementation of climate simulations with a better resolution would ameliorate the representation of spatial variability of the rainfall. As mentioned in Sect. 4.3 it is planned to use the results of the local climate model LM and FOOT3DK for further scenario modelling, but the results are not available yet. The comparison of simulated and measured rainfall data show that the rainfall quantities and the annual distribution of the rainfall fit good for the target region (Fig. 7 and Paeth, 2006 ${ }^{1}$ ). A slight overestimation of rainfall is visible for May and October, while in August and September the precipitation is underestimated. This tendentious deviation has also an impact on the scenario modelling for the year 2025, as shown in Sect. 5. Sindondji (2005) revealed that the frequency distribution of the rainfall 


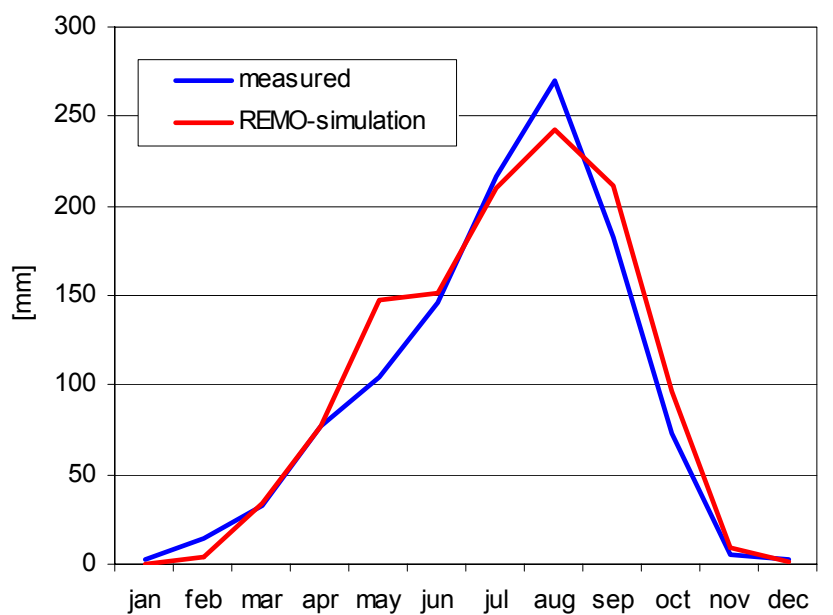

Fig. 7. Comparison of the measured rainfall of the rain gauge Partago and the rainfall for the corresponding pixel of the REMO simulation (1979-2003).

intensities simulated from REMO differs from the measured rainfall intensities because the model computes mean rainfall intensities over the grid. These uncertainties influence the modelled surface runoff and the simulated erosion rate, which was the focus of the study of Sintondji (2005).

As shown in Thamm et al. (2005) the LUCC model is able to explain the land cover change in the region with the chosen driving forces for the period 1991-2000. As a business as usual scenario was calculated in this study the uncertainties related to the land cover simulations can be assessed as relatively low. For further scenarios with a change of the economic development in the region (development scenarios B1 and B2) the estimation of the input parameters for the LUCC modelling will be more difficult as for the business as usual scenario. Therefore the uncertainty of these scenarios could be higher than for the scenario calculated here.

\section{Conclusions}

In the presented modelling approach the future water availability and water consumption of the Upper Ouémé catchment is assessed in an interdisciplinary scenario analysis. With the combination of LUCC, climate, demographic and hydrologic modelling with water consumption investigations all impacts on the future water availability can be assessed. As different models were used in this approach the uncertainties of all models have to bee taken into account.

The test run of the coupled models shows that the approach is applicable for an interdisciplinary scenario analysis in Benin. For the calculated scenario (development scenario B3 "business as usual" combined with IPCC scenario B2) a decrease of water resources in the region and an augmentation of water demand was calculated for the year 2025 . But as only one year was calculated in this study no general conclusion concerning the further water availability can be drawn. Even if the available water resources will be reduced as calculated in the scenario the region will not be subject to water scarcity considering the yearly water balance. The main problems concerning water availability in the region are the lack of renewable water in the dry season from December to April and the bad water supply infrastructure. Today over $60 \%$ of the population in some of the major communes of the Upper Ouémé catchment (Djougou, N'Dali and Tchaourou) has to use unsafe drinking water from rivers or unprotected wells.

Although the modelling and scenario concept described in this study is not able to solve these infrastructural problems, it can be an important step in the analysis and assessment of future water resource and establishes the basis of a sustainable water management in the region.

Acknowledgements. The authors would like to thank the German ministry of education and research (BMBF, grant No. 01 LW 0301A) as well as the MSWF Northrine-Westfalia (Grant No. 223-21200200) for the funding of the IMPETUS project in the framework of the GLOWA program. Thanks also to H.-P. Thamm and M. Judex, University of Bonn, for providing the land use classification of the Upper Ouémé valley. The climate simulations using the REMO model were provided by Dr. Paeth which is highly appreciated. The authors would also like to thank I. Gruber for providing the data concerning livestock water need. A special thank goes to the CATCH-project and the Direction Générale de l'Hydraulique (DGH) in Benin, who provided the discharge and precipitation data for the Upper Ouémé catchment.

Edited by: R. Barthel, J. Götzinger, G. Hartmann, J. Jagelke, V. Rojanschi, and J. Wolf

Reviewed by: anonymous referees

\section{References}

Bormann, H. and Diekkrüger, B.: A conceptual, regional hydrological model for Benin (West Africa): validation, uncertainty analysis and assessment of applicability for environmental change analyses, Phys. Chem. Earth, 29, 759-786, 2004.

Cosgrove, W. J. and Rijsberman, F. R.: World Water Vision. Making Water Everybody's Business, World Water Council, Earthscan Publications, London, 2000.

Doevenspeck, M.: Migration im ländlichen Benin, Sozialgeographische Untersuchungen an einer afrikanischen Frontier, Studien zur Geographischen Entwicklungsforschung, 30, 313p., 2005.

Faure, P.: Carte pédologique de Reconnaissance de la République Populaire du Bénin à 1:200000: Feuille Djougou, ORSTOM, Notice explicative no. 66(4), 49p., 1977.

Gaiser, T., Krol, M., Frischkorn, H., and de Araújo, J.C. (Eds.): Global Change and Regional Impacts: Water Availability and Vulnerability of Ecosystems and Society in the Semiarid Northeast of Brazil, Springer Berlin Heidelberg, 2003.

Giertz, S.: Analyse der hydrologischen Prozesse in den subhumiden Tropen Westafrikas unter besonderer Berücksichtigung der Landnutzung am Beispiel des Aguima-Einzugsgebietes in 
Benin, PhD-Thesis, University of Bonn, http://hss.ulb.uni-bonn. de/diss_online/math_nat_fak/2004/giertz_simone/index.htm, 2004.

Gruber, I. and Kuhn, A.: Land- und Wasserbedarf der Nutztierhaltung in Benin, IMPETUS, Sechster Zwischenbericht, 8690, http://www.impetus.uni-koeln.de/content/content_En_Pr_Do. php, 2006.

Hadjer, K., Klein, T., and Singer, U.: Wasser und Existenzsicherung, IMPETUS, Sechster Zwischenbericht, 198-206, http: //www.impetus.uni-koeln.de/content/content_En_Pr_Do.php, 2006.

Hadjer, K., Klein, T., and Schopp, M.: Water consumption embedded in its social context, north-western Benin, Phys. Chem. Earth, Special Issue, Vol. 30, 6-7, 357-364, 2005.

Heldmann, M.: Demographische Projektionen für das OuéméEinzugsgebiet, IMPETUS, Sechster Zwischenbericht, 184-191, http://www.impetus.uni-koeln.de/content/content_En_Pr_Do. php, 2006.

INSAE: Troisiéme Recensement Général de la Population et de l'Habitat de Février 2002. La population des communes de Tchaourou, N'dali, Parakou, Bassila, Djougou, Cotonou, Institut National de la Statistique et de l'Analyse Economique, Cotonou, Bénin, 2003.

INSAE: Troisième Recensement General de la population et de l'habitation, Fevrier 2002, Tome 6: Projections démographiques et étude prospective de la demande sociale au Bénin, 2004.

IPCC: Climate change 2001: The scientific basis, Contribution of the working group I to the third assessment report of the intergovernmental panel on climate change, Cambridge, 2001.

ISSS Working Group RB: World Reference Base for Soil Resources: Atlas. Acco, Leuven, 1998.

Judex, M.: Analyse und Erklärung der Landbedeckungs- und Landnutzungsänderung im Upper Oueme Catchment (Benin, Westafrika) durch die Verknüpfung von LANDSAT-Daten mit sozioökonomischen Daten, Diploma Thesis, University of Bonn, http://www.rsrg.uni-bonn.de/RSRGwww/Deutsch/ Diplomarbeiten/Judex_Diplomarbeit_2003.pdf, 2003.

Junge, B: Die Böden im oberen Ouémé-Einzugsgebiet: Pedogenese, Klassifikation, Nutzung und Degradierung, PhDThesis, University of Bonn, http://hss.ulb.uni-bonn.de/diss_ online/landw_fak/2004/junge_birte/index.htm, 2004.

Lahmer, W., Pfützner, B., and Becker, A.: Assessment of land use and climate change impacts on the mesoscale, Phys. Chem. Earth, 26, 7-8, 565-576, 2001.

Legesse, D., Vallet-Coulomba, C., and Gassea, F.: Hydrological response of a catchment to climate and land use changes in Tropical Africa: case study South Central Ethiopia, J. Hydrol., 275, 67-85, 2003.

Mimikou, M. A., Baltas, E., Varanou, E., and Pantazis, K.: Regional impacts of climate change on water resources quantity and quality indicators, J. Hydrol., 234, 95-109, 2000.

Mulindabigwi, V.: Influence des systèmes agraires sur l'utilisation des terroirs, la séquestration du carbone et la sécurité alimentaire dans le bassin versant de l'Ouémé supérieur au Bénin, PhDThesis, University of Bonn, 2005.

Ojo, O., Oni, F., and Ogunkunle, O.: Implications of climatic variability and climate change on water resources availability and water resources management in West Africa, in: Water Resources Systems - Water Availability and Global Change, edited by: Franks, S., Blöschl, G., Kumagai, M., Musiake, K., and D. Rosbjerg, IAHS Publication, 280, 37-47, 2003.

Orthmann, B.: Vegetation ecology of a woodland-savanna mosaic in central Benin (West Africa): Ecosystem analysis with a focus on the impact of selective logging, $\mathrm{PhD}$-Thesis, University of Rostock, http://www.impetus.uni-koeln.de, 2005.

Paeth, H.: Key factors in African climate change evaluated by a regional climate model, Erdkunde, 58, 290-315, 2004.

Paeth, H., Born, K., Podzun, R., and Jacob, D.: Regional dynamic downscaling over Westafrica: Model evaluation and comparison of wet and dry years, Meteorologische Zeitschrift, 14.3, 349367, 2005.

Penman, H. L: Evaporation: An introduction survey, Neth. J. AGR. Sci., 4, 8-29, 1956.

Pontius, R. and Schneider, L. C.: Land-use change model validation by the ROC method, Agriculture, Ecosystems and Environment, 85, 269-280, 2000.

Priestley, C. H. B. and Taylor, R. J.: On the assessment of surface heat flux and evaporation using large scale parameters, Mon. Wea. Rev., 100, 82-92, 1972.

SCS: Estimation of direct runoff from storm rainfall, National engineering handbook, Section 4 - Hydrology, USDA, 10.1-10.24, 1972.

Schopp, M.: Wasserversorgung in Benin unter Berücksichtigung sozioökonomischer und soziodemographischer Strukturen - Analyse der Wassernachfrage an ausgewählten Standorten des Haute Ouémé, PhD-Thesis, University of Bonn, http://hss.ulb.uni-bonn.de/diss_online/landw_fak/2005/ schopp_marion/index.htm, 2004.

Scurlock, J. M. O., Asner, G. P., and Gower, S. T.: Global Leaf Area Index Data from Field Measurements, 1932-2000, The Oak Ridge National Laboratory Distributed Active Archive Center, Oak Ridge, Tennessee, USA, 2001.

Sintondji, L. O.: Modelling the rainfall-runoff process in the Upper Ouémé catchment (Terou in Benin Republic) in a context of global change: extrapolation from local to regional scale, Shaker Publisher, Aachen, 2005.

Speth, P., Diekkrüger, B., and Christoph, M.: IMEPTUS West Africa - An integrated approach to the efficient management of scarce water resources in West Africa, in: German Programme on Global Change in the Hydrological Cycle (Phase I, 20002003), edited by: GSF - Forschungszentrum frr Umwelt und Gesundheit, Status Report, 61-67, 2002.

Speth, P., Diekkrüger, B., Christoph, M., and Jaeger, A.: IMPETUS West Africa - An integrated approach to the efficient management of scarce water resources in West Africa. in: GLOWA Global Change in the Hydrological Cycle, edited by: PT-DLR Projektträger im DLR, Status Report 2005, 86-94, 2005.

Thamm, H.-P., Judex, M., and Menz, G.: Modelling of Land-Use and Land-Cover Change (LUCC) in Western Africa using Remote Sensing, Zeitschrift für Photogrammetrie und Fernerkundung, 3/2005, 191-199, 2005.

Thamm, H.-P., Judex, M., Orekan, V., Stadler, C., Hiepe, C., Deng, X., and Heldmann, M.: Landnutzung und Landbedeckungsänderungen im Ouémé-Einzugsgebiet: Erfassung, Ursachen, Prognosen, Maßnahmen, IMPETUS, Sechster Zwischenbericht, 143-151, http://www.impetus.uni-koeln. de/content/content_En_Pr_Do.php, 2006. 
Turc, L.: Evaluation des besoins en eau d'irrigation, évapotranspiration potentielle, formulation simplifié et mise à jour, Ann. Agron., 12, 13-49, 1963.

Verburg, P. H.; Voldkamp, W. S. A., Espaldon, R. L. V and Mastura, S. S. A.: Modeling the Spatial Dynamics of Regional Land Use: The CLUE-S Model, in: Environmental Management, 30, 3, 391-405, 2002.

Verburg, P. H., Overmars, K. P., and Witte, N.: Accessibility and land use patterns at the forest fringe in the Northeastern part of the Philippines, The Geographical Journal, 170(3), 238-255, 2004.
Verburg, P. H., Veldkamp, A., Engelsman, W., van Zalinge, R., van Mensvoort, M. E. F., and Overmars, K. P: The use of models to assess the impact of and use change on ecological processes: case-studies of deforestation in SE Asia, in: Land use, nature conservation, and the stability of rainforest margins in Southeast Asia, edited by: Gerold, G., Fremerey, M., and Guhardja, E., 475-494, 2004a.

WASY: FEFLOW 5.1, Finite Element Subsurface Flow and Transport Simulation System, Institute of Water Resources Planning and System Research Ltd., Berlin, Germany, 2004. 